\title{
Interactive comment on "An experimental study on light scattering matrices for Chinese loess dust with different particle size distributions" by Jia Liu et al.
}

Jia Liu et al.

qixing@ustc.edu.cn

Received and published: 14 June 2020

The comment was uploaded in the form of a supplement:

https://www.atmos-meas-tech-discuss.net/amt-2019-236/amt-2019-236-AC3-

supplement.pdf

Interactive comment on Atmos. Meas. Tech. Discuss., doi:10.5194/amt-2019-236, 2019. 